\title{
DETECTING CUSTOMER DEFECTIONS: AN APPLICATION OF CONTINUOUS DURATION MODELS
}

\author{
*Sofia PORTELA \\ **Rui MENEZES \\ ISCTE - IUL, Research Center UNIDE.
}

\begin{abstract}
The considerable increase of business competition in the Portuguese fixed telecommunications industry for the last decades has given rise to a phenomenon of customer defection, which has serious consequences for the business financial performance and, therefore, for the economy. As such, researchers have recognised the importance of an in-depth study of customer defection in different industries and geographic locations. This study aims to understand and predict customer lifetime in a contractual setting in order to improve the practice of customer portfolio management. A duration model is developed to understand and predict the residential customer defection in the fixed telecommunications industry in Portugal. The models are developed by using large-scale data from an internal database of a Portuguese company which presents bundled offers of ADSL, fixed line telephone, pay-TV and home-video. The model is estimated with a large number of covariates, which includes customer's basic information, demographics, churn flag, customer historical information about usage, billing, subscription, credit, and other. The results of this study are very useful to the computation of the customer lifetime value
\end{abstract}

\section{Keywords:}

Survival models, customer churn, customer management

\section{INTRODUCTION}

Customer defection, i.e., the customer's decision to terminate the relationship with a provider, is a major concern for fixed telecommunications firms in Portugal. In fact, the considerable increase of business competition in the Portuguese fixed telecommunications industry over the last decades has given rise to a phenomenon of customer switching behaviour, and, thus, high customer churn rates, which has serious consequences for the financial performance of the firms and, therefore, for the economy. Several researchers have mentioned that customer churn is the main reason of profitability losses in the telecommunications industry, due to losses on current and potential revenues, marketing costs, and brand image (e.g., Ahn et al., 2006; Qian et al., 2006; Zhang et al., 2006).

As a consequence of this steady market growth, firms have been focused on customer acquisition and neglected customer retention. Nevertheless, the fixed telecommunications market is becoming saturated in Portugal and, as a consequence, the pool of "available customers" is limited and firms need to change their strategy from customer acquisition to customer retention (Hadden et al., 2005; Hung et al., 2006).

Customer retention became a buzzword in the 1990s, mainly due to the work of Reichheld and Sasser (1990), who firstly provided evidence about the advantages of customer retention. Even though their results are not consensual (see, for example, Carroll, 1991/92; Dowling and Uncles, 1997; East et al., 2006; Gupta et al., 2006; Reinartz and Kumar, 2000) they definitively caused a change in the marketing theory. Following this new paradigm, many firms have focused on retaining all customers. Nevertheless, many researchers argue that the retention strategy must be strongly linked with the customer lifetime value (i.e., the expected net present value of the future cash flows of the customer - CLV), and, consequently, enterprises should not try to retain all of their current customers, because they are probably investing in unprofitable customers (Gupta and Lehmann, 2003; Jain and Singh, 2002; Malthouse and Blattberg, 2004; Thomas et al., 2004), and, in this way, they are destroying value (Gupta and Lehmann, 2005; Jain and Singh, 2002) because (i) the retention of unprofitable customer

By fixed telecommunications industry we mean firms that provide fixed-line telephone, internet, and pay-TV. 
is damaging to the firm, and (ii) the money wasted on the retention of unprofitable is not used on the retention of profitable ones, who are harder to get (Thomas et al., 2004).

The customer churn issue is present both in studies about CLV as a component of CLV and on specific studies of churn, but in different perspectives. In studies about CLV, customer churn is mainly analysed in a theoretical way, whereas on the later case, the statistical models with empirical data are predominant. Furthermore, most studies which focus on CLV make strong assumptions about customer retention (i.e., the opposite of customer churn), such as customer retention is constant over time (e.g., Berger and Nasr, 1998; Blattberg and Deighton, 1996; Gupta and Lehmann, 2003; Gupta et al., 2004;) and across customers (Hogan et al., 2002). Nevertheless, the limitations of these assumptions are not recognised by all researchers.

Customer churn has been studied using different techniques, in different industries (e.g., banking, insurance, telecommunications), and in different contexts (contractual vs. noncontractual settings, continuous vs. discrete time). Buckinx and Van den Poel (2005), Hadden et al. (2005), Reinartz and Kumar (2003), Song et al. (2004), and Van den Poel and Larivière (2004) present literature reviews of customer churn studies. The Appendix 1 presents a review of the literature about customer churn prediction in the TI in contractual settings and continuous time, which is the scope of this study. Ahn et al. (2006) point out that the reasons of customer churn and the customer behaviour towards churn need to be more studied.

Despite the large amount of research done on customer churn in mobile telecommunications, there are few studies applied to the fixed telecommunications industry and none applied to firms that provide bundled offers of fixed telecommunications services. Moreover, this issue has never been studied in Portugal. So, this study aims to develop a model of the residential customer churn in the fixed telecommunications industry in Portugal. Specifically, this study intends to estimate the probability of a given active customer cancels his/her relationship with the firm in the next period. Some of the specific areas where this model can help customer management are: (i) a priori knowledge about the probability (risk) of a given customer to cancel the relationship with the firm in the next period and, in this way, firms can take preventive measures to avoid the defection of potentially profitable customers, (ii) customer selection to retention programs; (iii) marketing resource allocation across customers; and (iv) computation of customer lifetime value.

\section{METHODS}

A continuous survival analysis will be used to understand the residential customer churn in the FT

industry (contractual settings) in Portugal. Let $T$ be a continuous non-negative random variable, which represents the survival time in days. Two key concepts in survival analysis are the survival and the hazard function. The survival function is the probability of an individual to survive beyond time

$t$ and the hazard function is the instantaneous potential per unit time for the event occurrence (customer churn), given that the individual has survived up to time ${ }^{t}$. Survival models can accommodate both the proportional hazards (PH) and the accelerated failure time (AFT) forms. PH models assume that the hazard rates of any two individuals are proportional over time and that the hazard ratio is constant over time, and as such, the effect of any covariate in the hazard function is constant over time. AFT models assume that there is a constant non-negative acceleration factor that stretches out or shrinks survival times. AFT models are linear models of $\ln (T)$.

Data were obtained from a Portuguese fixed telecommunications firm which presents bundled offers of ADSL, fixed line telephone, pay-TV and home-video. The database includes a random sample of 830 residential customers who completed a questionnaire about customer satisfaction. The available data contains a large number of covariates, which include customer's basic information, demographics, churn flag, customer historical information about usage, billing, subscription, credit, and other.

In this study, a customer is active if he/ she has currently at least one contract with the firm. In other words, for this analysis, a customer defects only when he/she stops buying all of the company services. 


\section{RESULTS Model estimation}

A Cox PH model was estimated in order to test the PH assumption based on Schoenfeld residuals. We found statistical evidence that the PH assumption does not hold $(p=0.004)$; so, AFT models will be used instead. As all AFT models are parametric models, the data distribution has to be postulated in advance. In order to decide which parametric model is more appropriate for our data, we adopted two statistical strategies as suggested by Cleves et al. (2004). As regards to the nested models, we estimated a generalized gamma model and we tested its free parameters. It can be concluded that there is statistical evidence that the model can be a log-normal $(p=0.141)$ or a Weibull $(p=0.670)$ but not an exponential $(p<0.01)$. Then, with the purpose of examining all the models (nested and non-nested), we compared them based on the AIC. It seems that the model that best fit the data is the log-logistic, because it has the lowest AIC.

A log-logistic model with gamma-distributed frailty (unshared) was estimated in order to test the unobserved individual heterogeneity. There is statistical evidence that this effect is presented $\left(\mathrm{H}_{0}: \theta=0\right.$; $p=0.077$ ), and thus, it has to be included in the model, since it improves the results. The covariates are presented in table 1 and our final model is presented in table 2.

In AFT models, the estimated coefficients are interpreted taking the survival time as reference (BoxSteffensmeier and Jones, 2004). Thus, continuous covariates with positive coefficients have a positive effect on survival time (and, consequently, a negative effect on the hazard function) and those with negative coefficients negatively affects the survival time (Box-Steffensmeier and Jones, 2004; Cleves et al., 2004).

Our results show that overall revenues positively affect the survival time, which is consistent with the results of Jamal and Bucklin (2006). Zhang et al. (2006) also found that the overall revenues from the last 6 months affects the survival time of customers. The results of the present study also appear to indicate that survival time increases as the monthly average of off-peak calls increase. Contrary to expectations, it seems that the value of current debts of the customer has a positive effect on survival time. This can be due to the fact that, until recently, the firm's policy was not stopping the service to customers with debts. Ahn et al. (2006) did not find any relationship between the value of current debts and survival time.

TABLE 1 - DEFINITION OF THE SIGNIFICANT COVARIATES

\begin{tabular}{ll}
\hline \multicolumn{1}{c}{ Covariates } & \multicolumn{1}{c}{ Description } \\
\hline Gender & Gender of the customer (0 - female; $1-$ male) \\
\hline Total dunning & Total number of overdue bills since ever \\
\hline Overall revenues & Total revenues from the customer since ever (in euros) \\
\hline Debts & Value of current debt (in euros) \\
\hline $\begin{array}{l}\text { Value of off-peak } \\
\text { calls }\end{array}$ & $\begin{array}{l}\text { Monthly average of off-peak calls between December 2007 and November } \\
\text { 2008 (in euros) }\end{array}$ \\
\hline Telephone revenues & $\begin{array}{l}\text { Monthly average of the revenues from the fixed-telephone service between De- } \\
\text { cember 2007 and November 2008 (in euros) }\end{array}$ \\
\hline Internet revenues & $\begin{array}{l}\text { Monthly average of the revenues from the internet service between December } \\
\text { 2007 and November 2008 (in euros) }\end{array}$ \\
\hline
\end{tabular}




\section{TABLE 2 - ESTIMATES OF THE LOG-LOGISTIC MODEL WITH GAMMA-DISTRIBUTED UNSHARED FRAILTY}

\begin{tabular}{lc}
\hline & Log-logistic \\
\hline Gender & $.432 * * *$ \\
Total dunning & $-.439 * * *$ \\
Overall revenues & $.001 * * *$ \\
Debts & $.008^{* * *}$ \\
Gender $\times$ Overall revenues & $-.000^{* * *}$ \\
Value of off-peak calls & $.263 * *$ \\
Telephone revenues & $-.039 * * *$ \\
Internet revenues & $-.019 * * *$ \\
constant & $6.243 * * *$ \\
Ln sigma & $-2.466 * * *$ \\
sigma & .085 \\
Ln theta & .522 \\
theta & 1.685
\end{tabular}

On the other hand, it seems that the total number of overdue bills (since ever), the monthly average of customer spending both on fixed-telephone and internet negatively affect the survival time. Even though some authors have found similar evidence about the monthly revenues (e.g., Ahn et al., 2006; Bolton, 1998; and Madden et al., 1999), other found the opposite (e.g., Kim and Yoon, 2004). This indicates that customers are very sensitive to pricing.

The results of the present study also indicate that the survival time for males is larger than the one for females, which is consistent with Ahn et al. (2006) and Seo et al. (2007), but contradicts Kim and Yoon (2004) and Madden et al. (1999). Furthermore, it seems that the effect of overall revenues on survival time for females is larger than for males.

Contrary to our prior expectations, customer satisfaction is not a significant covariate, which suggests that customer satisfaction in this context is not a reason for customer churn. A possible explanation of this finding is that even though the customer is not satisfied, he/she may do not switch due to inertia or habit. This contradicts the majority of literature about satisfaction (e.g., Bolton, 1998; Eshghi et al., 2007). Kim and Yoon (2004) found that whereas some types of satisfaction positively affects survival time, other do not have any influence. Van den Poel and Larivière (2004) present some studies that did not find any effect of satisfaction on survival time.

Moreover, results also appear to indicate that both the telephone and internet usage do not influence customer churn, which contrasts with the findings of Ahn et al. (2006), who found a positive relationship between usage and survival time. We also provide evidence that the payment method and the number of invoices in debt do not influence the customer churn. Nevertheless, Zhang et al. (2006) show that the payment method affects the customer churn.

Lastly, the results suggest that the customer retention rate is neither constant over time (the exponential model is the only one which hazard function is constant and this model does not definitely adequately fits the data) nor across customers (because the PH assumption is not satisfied), which contradicts a common assumption made by several researchers on the CLV computation, as mentioned above. Schweidel et al. (2008) also provide evidence that the hazard rates vary across customers. The hazard and survival functions of this model are presented in Exhibits 1 and 2, respectively. 
EXHIBIT 1 - HAZARD CURVE

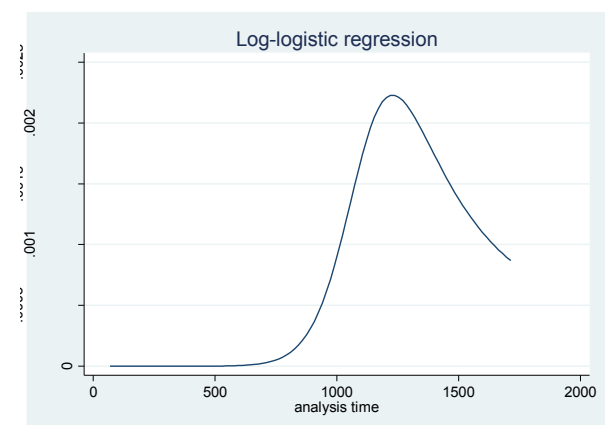

EXHIBIT 2 - SURVIVAL CURVE

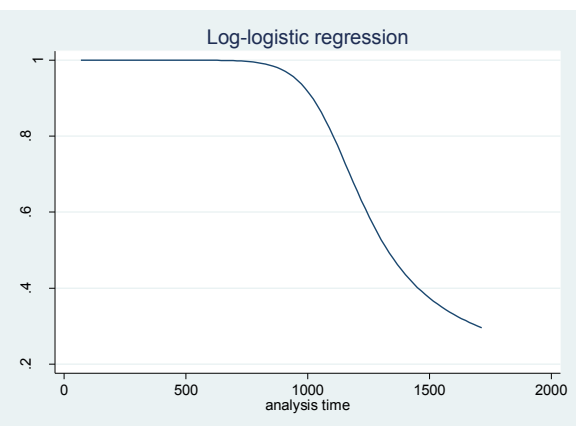

As can be seen from the analysis of the population hazard curve, there is duration dependence. In fact, the probability that a given mean customer cancels his relationship with the service provider increases as the customer lifetime increases (for relationships with less than approximately 3.5 years), and then decreases. Different studies have also obtained duration dependence (e.g., Kim and Yoon, 2004; Schweidel et al., 2008; Seo et al., 2007; Zhang et al., 2006).

\section{Goodness-of-fit}

The goodness of fit of the model is tested by plotting the Nelson-Aalen cumulative hazard estimator for Cox-Snell residuals, which is presented in Figure 3. From the analysis of this graph, it can be concluded that the model adequately fits the data.

\section{EXHIBIT 3 - CUMULATIVE HAZARD OF COX-SNELL RESIDUALS}

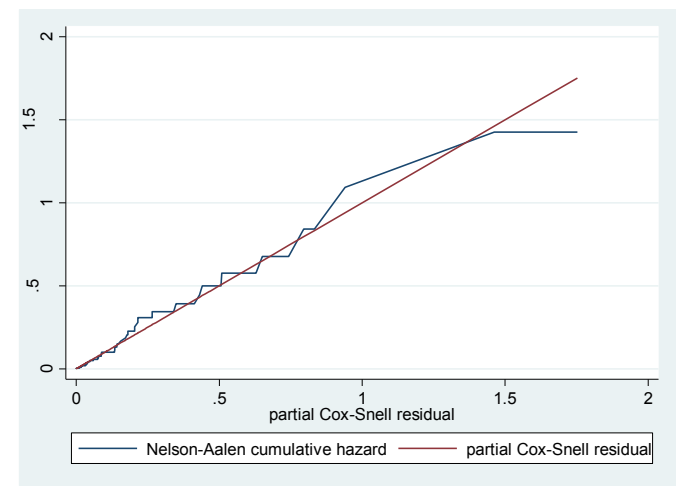

\section{CONCLUSIONS}

This study sheds new light on the crucial issue of customer churn in the FT industry in Portugal. Considering that it is crucial to prevent the churn of profitable customers in order to ensure the financial performance of these firms, the results of this study are very valuable mainly when complemented with an analysis of the CLV for each individual.

These results have a number of managerial implications. Firstly, firms cannot make decisions about customer management based on the average churn rates. Secondly, it appears that firms should concentrate less on customer satisfaction because it does not seem to be an important reason of customer churn, and instead focus on pricing strategy.

\section{ACKNOWLEDGMENTS}

We wish to thank the firm that provided their internal customer database, without which this study would be not possible, and who strongly believe on the importance of the expected results to the improvement of its customer portfolio management. We also thank the Fundação para a Ciência e Tecnologia for its financial support (Project reference: PTDC/GES/73418/2006). 


\section{APPENDIX - SUMMARY OF THE LITERATURE REVIEW ON CUSTOMER CHURN IN \\ THE TI IN CONTRACTUAL SETTINGS AND CONTINUOUS TIME}

\begin{tabular}{|c|c|c|c|c|}
\hline & Scope of the study & Industry & Region & Technique \\
\hline Ahn et al. (2006) & $\begin{array}{l}\text { 5) Development of a comprehensive churn model of private } \\
\text { users } \\
\text { Analysis of the mediating effects of a customer's partial } \\
\text { defection on the relationship between the churn } \\
\text { determinants and total defection }\end{array}$ & $\begin{array}{l}\text { Mobile Telecom- } \\
\text { munications }\end{array}$ & $\begin{array}{l}\text { South } \\
\text { Korea }\end{array}$ & Logistic regression \\
\hline Bin et al. (2007) & Churn prediction & $\begin{array}{l}\text { Personal handy- } \\
\text { phone system } \\
\text { service }\end{array}$ & China & Decision trees \\
\hline Bolton (1998) & $\begin{array}{l}\text { Develop and estimate a duration model focused on the } \\
\text { effect of customer satisfaction }\end{array}$ & $\begin{array}{l}\text { Mobile Telecom- } \\
\text { munications }\end{array}$ & n.a. & Survival analysis \\
\hline $\begin{array}{l}\text { Bonfrer et al. } \\
\text { (2007) }\end{array}$ & $\begin{array}{l}\text { Estimate the customer churn } \\
\text { Examination of these models in the CLV calculation }\end{array}$ & $\begin{array}{l}\text { Mobile Telecom- } \\
\text { munications }\end{array}$ & China & $\begin{array}{l}\text { Arithmetic Brownian motion } \\
\text { Geometric Brownian motion }\end{array}$ \\
\hline $\begin{array}{l}\text { Burez and } \\
\text { Van den Poel } \\
(2007)\end{array}$ & $\begin{array}{l}\text { Development of the three different churn-prediction } \\
\text { models } \\
\text { Targeting of customers } \\
\text { Analysis of three different customer retention strategies }\end{array}$ & Pay-TV & Europe & $\begin{array}{l}\text { Logistic regression } \\
\text { Markov chains } \\
\text { Random forests }\end{array}$ \\
\hline $\begin{array}{l}\text { Burez and } \\
\text { Van den Poel } \\
(2008)\end{array}$ & $\begin{array}{l}\text { Investigate churn using both static and dynamic churn } \\
\text { prediction models } \\
\text { Separate financial from commercial churn }\end{array}$ & Pay-TV & Europe & $\begin{array}{l}\text { Survival analysis - KM (dynamic) } \\
\text { Random forests (static) }\end{array}$ \\
\hline $\begin{array}{l}\text { Eshghi et al. } \\
\text { (2007) }\end{array}$ & $\begin{array}{l}\text { Investigate the propensity to switch wireless service } \\
\text { providers }\end{array}$ & $\begin{array}{l}\text { Mobile Telecom- } \\
\text { munications }\end{array}$ & US & Structural equation model \\
\hline $\begin{array}{l}\text { Hung et al. } \\
\text { (2006) }\end{array}$ & $\begin{array}{l}\text { Compare various data mining techniques that can assign a } \\
\text { "propensity-to-churn" score periodically to each sub- } \\
\text { scriber }\end{array}$ & $\begin{array}{l}\text { Mobile Telecom- } \\
\text { munications }\end{array}$ & Taiwan & $\begin{array}{l}\text { K-means clustering } \\
\text { Decision tree } \\
\text { Back propagation neural networks }\end{array}$ \\
\hline $\begin{array}{l}\text { Jamal and } \\
\text { Bucklin (2006) }\end{array}$ & $\begin{array}{l}\text { Develop a survival model to predict customer churn } \\
\text { Study the link between customer churn and some factors }\end{array}$ & $\begin{array}{l}\text { Direct-to-home } \\
\text { satellite TV }\end{array}$ & $\begin{array}{c}\text { South } \\
\text { America }\end{array}$ & Survival analysis \\
\hline $\begin{array}{l}\text { Kim and } \\
\text { Yoon (2004) }\end{array}$ & Identify the determinants of customer churn and loyalty & $\begin{array}{l}\text { Mobile Telecom- } \\
\text { munications }\end{array}$ & Korea & Binomial logit \\
\hline $\begin{array}{l}\text { Lemmens and } \\
\text { Croux (2006) }\end{array}$ & $\begin{array}{l}\text { Analyse if the bagging and boosting classification tech- } \\
\text { niques outperform the binary logit model in predicting } \\
\text { churn (predict if a subscriber churn in the next } 31 \text { to } 60 \\
\text { days) }\end{array}$ & $\begin{array}{l}\text { Mobile Telecom- } \\
\text { munications }\end{array}$ & US & $\begin{array}{l}\text { Logistic regression } \\
\text { Bagging } \\
\text { Stochastic gradient boosting }\end{array}$ \\
\hline $\begin{array}{l}\text { Madden et al. } \\
\text { (1999) }\end{array}$ & $\begin{array}{l}\text { Analyse the probability of subscriber churn (residential } \\
\text { users) }\end{array}$ & ISP & Australia & Binomial probit \\
\hline $\begin{array}{l}\text { Mani et al. } \\
\text { (1999) }\end{array}$ & $\begin{array}{l}\text { Modelling the duration of the customer relationship with } \\
\text { a service provider }\end{array}$ & $\begin{array}{l}\text { Mobile Telecom- } \\
\text { munications }\end{array}$ & US & $\begin{array}{l}\text { Classical survival analysis } \\
\text { Neural networks for survival analysis }\end{array}$ \\
\hline $\begin{array}{l}\text { Mozer et al. } \\
(2000)\end{array}$ & $\begin{array}{l}\text { Explore statistical techniques for churn prediction (in the } \\
\text { next } 2 \text { months) } \\
\text { Evaluation of how these predictions could be used for } \\
\text { decision making } \\
\text { Identify customers to whom incentives should be offered } \\
\text { to increase retention }\end{array}$ & $\begin{array}{l}\text { Mobile Telecom- } \\
\text { munications (multi- } \\
\text { service subscribers) }\end{array}$ & US & $\begin{array}{l}\text { Logistic regression } \\
\text { Nonlinear neural networks }\end{array}$ \\
\hline $\begin{array}{l}\text { Neslin et al. } \\
(2006)\end{array}$ & $\begin{array}{l}\text { Identify which methodological approaches work best for } \\
\text { predicting customer churn (in the next } 3 \text { months) }\end{array}$ & $\begin{array}{l}\text { Mobile Telecom- } \\
\text { munications }\end{array}$ & n.a. & $\begin{array}{l}\text { Logistic regression } \\
\text { Decision trees } \\
\text { Neural networks } \\
\text { Discriminant analysis }\end{array}$ \\
\hline $\begin{array}{l}\text { Qian et al. } \\
\text { (2006) }\end{array}$ & $\begin{array}{l}\text { Profile customer behaviour in order to identify and cap- } \\
\text { ture churn activity patterns }\end{array}$ & $\begin{array}{l}\text { Telecommunica- } \\
\text { tions }\end{array}$ & n.a. & Functional mixture model \\
\hline $\begin{array}{l}\text { Schweidel } \text { et al. } \\
(2008)\end{array}$ & Modelling customer retention within and across cohorts & $\begin{array}{l}\text { Telecommunica- } \\
\text { tions }\end{array}$ & n.a. & Survival analysis \\
\hline Seo et al. (2007) & $\begin{array}{l}\text { Understanding the factors related to customer retention } \\
\text { behaviour }\end{array}$ & $\begin{array}{l}\text { Mobile Telecom- } \\
\text { munications }\end{array}$ & US & $\begin{array}{l}\text { Logistic regression } \\
\text { Hierarquical linear model (HLM) }\end{array}$ \\
\hline $\begin{array}{l}\text { Wei and Chiu } \\
(2002)\end{array}$ & Churn prediction (in the next month) & $\begin{array}{l}\text { Mobile Telecom- } \\
\text { munications }\end{array}$ & Taiwan & Decision trees \\
\hline $\begin{array}{l}\text { Zhang et al. } \\
\text { (2006) }\end{array}$ & Churn prediction (in the next month) & $\begin{array}{l}\text { Fixed-line } \\
\text { telephone }\end{array}$ & China & $\begin{array}{l}\text { Several data mining techniques } \\
\text { (decision trees, neural networks, and } \\
\text { regression) }\end{array}$ \\
\hline
\end{tabular}




\section{REFERENCES}

Ahn, J-H., S-P., Han, and Y-S. Lee (2006). "Customer Churn Analysis: Churn Determinants and Mediation Effects of Partial Defection in the Korean Mobile Telecommunications Service Industry", Telecommunications Policy, 30 (10-11), pp.552-568.

Berger, P. D. and Nasr, N. I. (1998). "Customer Lifetime Value: Marketing Models and Applications", Journal of Interactive Marketing, 12 (1), pp.17-30.

Bin, L., Peiji, S. and Juan, L. (2007). "Customer Churn Prediction Based on the Decision Tree in Personal Handyphone System Service", Proceedings of the International Conference on Service Systems and Service Management.

Blattberg, R. C. and Deighton, J. (1996). "Manage Marketing by the Customer Equity Test”, Harvard Business Review, 74 (4), pp.136-144.

Bolton, R. N. (1998). "A Dynamic Model of the Duration of the Customer's Relationship with a Continuous Service Provider: The Role of Satisfaction”, Marketing Science, 17 (1), pp.45-65.

Bolton, R. N., and Tarasi, C. O. (2006). Managing Customer Relationships”, Review of Marketing Research, 3, pp.3-38.

Bonfrer, A., Knox, G., Eliashberg, J., and Chiang, J. (2007). "Diagnosing and Predicting Individual Customer Defection in a Contractual Setting", Working Paper.

Box-Steffensmeier, J. M., and Jones, B. S. (2004). "Event History Modeling: A Guide for Social Scientists", Cambridge University Press, Cambridge.

Buckinx, W, and Van den Poel, D (2005). "Customer base analysis: partial defection of behaviourally loyal clients in a non contractual FMCG retail setting", European Journal of Operational Research, 164 (1), pp.252-268.

Burez, J., and Van den Poel, D. (2007). "CRM At a Pay-TV Company: Using Analytical Models to Reduce Customer Attrition by Targeted Marketing for Subscription Services", Expert Systems with Applications, 32 (2), pp.277-288.

Burez, J., and Van den Poel, D. (2008). "Separating Financial from Commercial Customer Churn: A Modeling Step Towards Resolving the Conflit Between the Sales and Credit Department", Expert Systems with Applications, 35, pp.497-514.

Carroll, P. (1991/92). “The Fallacy of Customer Retention”, Journal of Retail Banking, 13 (4), 15-20.

Cleves, M. A., Gould, W. W. and Gutierrez, R. G. (2004). "An Introduction to Survival Analysis using STATA", STATA Press.

Dowling, G.R., and M. Uncles (1997). "Do Customer Loyalty Programs Really Work?”, Sloan Management Review, 38 (4), pp.71-82.

East, R., K. Hammond, and P. Gendall (2006). "Fact and Fallacy in Retention Marketing", Journal of Marketing Management, 22 (1), pp.5-23.

Eshghi, A., Haughton, D., and Topi, H. (2007). "Determinants of Customer Loyalty in the Wireless Telecommunications Industry", Telecommunications Policy, 31 (2), pp.93-106.

Grant, A. W. H. and Schlesinger, L. A. (1995). "Realize Your Customers' Full Profit Potential”, Harvard Business Review, 73 (5), pp.59-72.

Gupta, S. and Lehmann, D. R. (2003). "Customers as Assets", Journal of Interactive Marketing, 17 (1), pp.9-24.

Gupta, S. and Lehmann, D. R. (2005), Managing Customers as Investments: The Strategic Value of Customers in the Long Run, Wharton School Publishing.

Gupta, S., D. Hanssens, B. Hardie, W. Kahn, V. Kumar, N. Lin, N. Ravishanker, and S. Sriram (2006). "Modeling Customer Lifetime Value", Journal of Service Research, 9 (2), pp.139-155.

Gupta, S., Lehmann, D. R. and Stuart, J. A. (2004). "Valuing Customers", Journal of Marketing Research, 41 (1), pp.7-18. 
Hadden, J., A. Tiwari, R. Roy, and D. Ruta (2005). “Computer Assisted Customer Churn Management: State-Of-The-Art and Future Trends", Computers \& Operations Research, 34 (10), pp.29022917.

Hogan, J. E., Lehmann, D. R., Merino, M., Srivastava, R. K., Thomas, J. S. and Verhoef, P. C. (2002). "Linking Customer Assets to Financial Performance", Journal of Service Research, 5 (1), pp.26-38.

Hung, S-Y., D.C. Yen, and H-Y. Wang (2006). “Applying Data Mining to Telecom Churn Management”, Expert Systems with Applications, 31 (3), pp.515-524.

Jain, D. and Singh, S. S. (2002). "Customer Lifetime Value Research in Marketing: A Review and Future Directions", Journal of Interactive Marketing", 16 (2), pp.34-46.

Jamal, Z., and Bucklin, R. E. (2006). "Improving the Diagnosis and Prediction of Customer Churn: A Heterogeneous Hazard Modeling Approach", Journal of Interactive Marketing, 20 (3-4), pp.16-29.

Kim, H.-S., and Yoon, C.-H. (2004). "Determinants of Subscriber Churn and Customer Loyalty in the Korean Mobile Telephony Market”, Telecommunications Policy, 28 (9-10), pp.751-765.

Lemmens, A., and Croux, C. (2006). "Bagging and Boosting Classification Trees to Predict Churn", Journal of Marketing Research, 43 (2), pp.276-286.

Madden, G., Savage, S. J., and Coble-Neal, G. (1999). "Subscriber Churn in the Australian ISP Market”, Information Economics and Policy, 11 (2), pp.195-207.

Malthouse, E. C. and Blattberg, R. C. (2004). “Can We Predict Customer Lifetime Value?”, Journal of Interactive Marketing, 19 (1), pp.2-16.

Mani, D. R., Drew, J., Betz, A., and Datta, P. (1999). "Statistics and Data Mining Techniques for Lifetime Value Modelling", Proceedings of the fifth ACM SIGKDD International Conference on Knowledge Discovery and Data Mining, pp.94-103.

Mozer, M. C., Wolniewicz, R., Grimes, D. B., Johnson, E., and Kaushansky, H. (2000). “Churn Reduction in the Wireless Industry", Advances in Neural Information Processing Systems 12, MIT Press, Cambridge, MA., pp.935-941.

Neslin, S. A., Gupta, S., Kamakura, W., Lu, J., and Mason, C. H. (2006). "Defection Detection: Measuring and Understanding the Predictive Accuracy of Customer Churn Models", Journal of Marketing Research, 43 (2), pp.204-211.

Qian, Z., W. Jiang, and K-L. Tsui (2006). “Churn Detection via Customer Profile Modelling”, International Journal of Production Research, 44 (14), pp.2913-2933.

Ranaweera, C. (2007). "Are Satisfied Long-Term Customers More Profitable? Evidence from the Telecommunication Sector", Journal of Targeting, Measurement and Analysis for Marketing, 15 (2), pp.113-120.

Reichheld, F.F., and W.E. Sasser (1990). "Zero Defections: Quality Comes to Services", Harvard Business Review, 68 (5), pp.105-111.

Reinartz, W, and Kumar, V (2003). "The impact of customer relationship characteristics on profitable lifetime duration", Journal of Marketing, 67 (1), pp.77-99.

Reinartz, W. and Kumar, V. (2000). "On the Profitability of Long-Life Customers in a Noncontractual Setting: An Empirical Investigation and Implications for Marketing", Journal of Marketing, 64 (4), pp.17-35.

Schweidel, D. A., Fader, P. S., and Bradlow, E. T. (2008). "Modeling Retention Within and Across Cohorts", Journal of Marketing, 72 (1), pp.82-94.

Seo, D. B., Ranganathan, C., and Babad, Y. (2007). "Two-Level Model of Customer Retention in the US Mobile Telecommunications Service Market”, Telecommunications Policy, pp.1-15.

Song, H S, Kim, J K, Cho, Y B, and Kim, S H (2004). “A personalized defection detection and prevention procedure based on the self-organizing map and association rule mining: applied to online game site”, Artificial Intelligence Review, 21 (2), pp.161-184.

Thomas, J. S., Reinartz, W. and Kumar, V. (2004). "Getting the Most Out of All Your Customers", Harvard Business Review, 82 (7/8), pp.116-123. 
Van den Poel, D, and Larivière, B (2004). "Customer attrition analysis for financial services using proportional hazard models”, European Journal of Operational Research, 157 (1), pp.196-217.

Wei, C.-P., and Chiu, I. T. (2002). "Turning Telecommunications Call Details to Churn Prediction: A Data Mining Approach", Expert Systems with Applications, 23 (2), pp.103-112.

Zhang, Y., J. Qi, H. Shu, and Y. Li (2006). "Case Study on CRM: Detecting Likely Churners with Limited Information of Fixed-Line Subscriber", Proceedings of the International Conference on Service Systems and Service Management (vol 2), pp.1495-1500. 